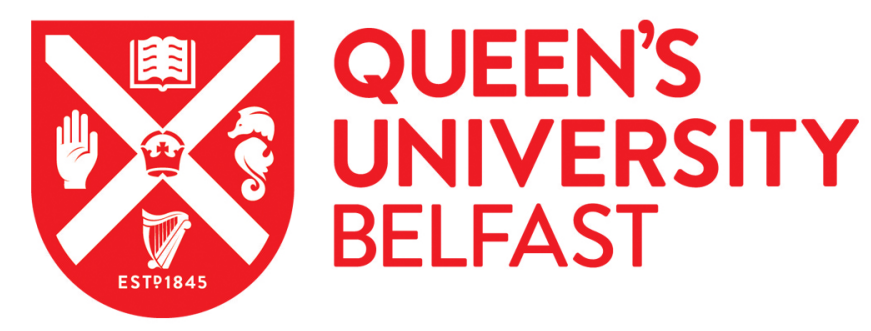

\title{
The effect of area based urban regeneration policies on fuel poverty: Evidence from a natural experiment in Northern Ireland
}

Mohan, G., Longo, A., \& Kee, F. (2018). The effect of area based urban regeneration policies on fuel poverty: Evidence from a natural experiment in Northern Ireland. Energy Policy, 114, 609-618.

https://doi.org/10.1016/j.enpol.2017.12.018

\section{Published in:}

Energy Policy

\section{Document Version:}

Peer reviewed version

Queen's University Belfast - Research Portal:

Link to publication record in Queen's University Belfast Research Portal

\section{Publisher rights}

Copyright 2017 the authors.

This is an open access article published under a Creative Commons Attribution-NonCommercial-NoDerivs License

(https://creativecommons.org/licenses/by-nc-nd/4.0/), which permits distribution and reproduction for non-commercial purposes, provided the author and source are cited.

\section{General rights}

Copyright for the publications made accessible via the Queen's University Belfast Research Portal is retained by the author(s) and / or other copyright owners and it is a condition of accessing these publications that users recognise and abide by the legal requirements associated with these rights.

\section{Take down policy}

The Research Portal is Queen's institutional repository that provides access to Queen's research output. Every effort has been made to ensure that content in the Research Portal does not infringe any person's rights, or applicable UK laws. If you discover content in the Research Portal that you believe breaches copyright or violates any law, please contact openaccess@qub.ac.uk. 
The effect of area based urban regeneration policies on fuel poverty: Evidence from a natural experiment in Northern Ireland.

Gretta Mohan, Alberto Longo, Frank Kee

\section{Abstract}

This paper studies the effect of the most extensive area based regeneration policy in Northern Ireland - Neighbourhood Renewal (NR) - on fuel poverty using a natural experiment approach. NR was launched in 2003 in Northern Ireland as a holistic area-based regeneration policy to improve the lives, prospects and environments of residents living in thirty-six of the nation's most deprived areas over a seven- to ten- year roll-out. Using data from the Northern Ireland Household Panel Survey and from the Understanding Society survey, the effect on fuel poverty during a twelve year period is investigated. Difference-in-difference regression modelling of the impact of NR on fuel poverty provides evidence of a $3.0 \%$ reduction in fuel poverty comparing respondents in NR areas with the rest of Northern Ireland and a $4.7 \%$ decline relative to a similarly deprived control group. When the effect on heterogeneous characteristics of the sample is explored, the analysis reveals that NR has been particularly effective in relieving fuel poverty among groups with lower qualifications, the retired and those receiving benefits, and has therefore contributed to a reduction in inequalities within the most deprived areas in Northern Ireland.

\section{Keywords}

Fuel poverty, fuel expenditures, area based initiatives, urban regeneration, longitudinal analysis, difference-in-difference. 
Abbreviations

NR - Neighbourhood Renewal

NRA - Neighbourhood Renewal Area

NIHPS - Northern Ireland Household Panel Survey

$\mathrm{Cl}$ - Confidence Interval 


\section{Introduction}

An occupant is considered to be living in a fuel poor household if the household is unable to maintain sufficient home warmth and domestic energy services at a reasonable cost. The UK government introduced a Fuel Poverty Strategy in 2001 as a commitment to ensure that no vulnerable households would be fuel poor by 2010 (Department of the Environment, Transport and the Regions and Department of Trade and Industry, 2001). Northern Ireland has the highest prevalence of fuel poverty in the UK (Northern Ireland Housing Executive, 2013), attributable to a combination of a cooler climate, lower incomes and higher dependence on more expensive forms of heat such as oil, solid fuel and electricity. The prevailing definition of a fuel poor household in Northern Ireland is one which must spend in excess of ten-percent of household income to service fuel requirements (Department for Social Development, 2011a, 2004). In developed countries characterised by a temperate climate, fuel poverty is regarded as a form of social inequality and injustice (Braubach and Ferrand, 2013; Marmot, 2011; Roberts, 2008; Walker and Day, 2012; Wilkinson et al., 2007). Fuel poverty is a political and health priority because of its increasingly evidenced adverse impacts on physical and mental health, the role it plays in excess winter deaths as well as its social implications (Balfour and Allen, 2014; Liddell and Morris, 2010; Marmot, 2011). The prevalence of fuel poverty may be more acute in disadvantaged neighbourhoods marked by socioeconomic and physical deprivation due to lower household incomes and poorer housing stock (Curl and Kearns, 2016; Walker et al., 2013; Webber et al., 2015).

A major urban regeneration programme, Neighbourhood Renewal (NR) in Northern Ireland began in 2003 to improve the environmental conditions, prospects and quality of life for residents of thirty-six urban neighbourhoods throughout the nation characterised by the highest levels of deprivation (Department for Social Development, 2003). Fifteen NR areas (NRAs) were established in Belfast, six in the North West including four in the city of Derry/Londonderry and fifteen in smaller cities and 
towns across Northern Ireland. These NRAs accounted for one in six of the Northern Ireland population, 278,000 persons according to the 2001 census. The policy was designed to be long term, operating over a seven to ten year horizon, acting as a catalyst for sustained coordinated investment across four interlinking objective areas - community, economic, social and physical renewal. The NR programme was based on the premise that transforming neighbourhoods hinges on community empowerment in cooperation with statutory bodies and delivery agencies (Atkinson, 1999; Foley and Martin, 2000; Meegan and Mitchell, 2001; Social Exclusion Unit, 2001). Accordingly, NR Partnerships, consisting of voluntary, community, statutory, political and private sector stakeholders, were established in each NRA. These acted as a vehicle to identify the most pressing issues in the locality and directed the response to local problems in planning and implementation. Each partnership produced a long term vision statement outlining challenges, priorities and aspirations for the roll out of the Strategy as well as three-year action plans detailing local schemes designed to achieve NR objectives in the area. The action plans and annual reports from NR partnerships specify that addressing fuel poverty was an important objective (Downpatrick Neighbourhood Renewal Partnership, 2010; Greater Falls Neighbourhood Renewal Partnership, 2013; Strabane Neighbourhood Renewal Partnership, 2012; Triax Neighbourhood Renewal Partnership Board, 2011).

The operation of the $\mathrm{f} 194$ million community-led, state-sponsored, NR urban regeneration policy is hypothesized to ease fuel poverty in policy-on areas over a decade of implementation. The statutory government evaluations of the NR policy did not consider the impact of NR on fuel poverty (Department for Social Development, 2011b; RSM McClurre Waters, 2014), and thus this study adds to the assessment of the effect of the policy on an unexplored measure. Using data from the Northern Ireland Household Panel Survey and the Understanding Society survey, difference-indifference regression modelling in a natural experiment setting is applied to investigate how fuel poverty has been affected by the introduction of the NR policy. To the authors' knowledge, this 
paper presents novel research in the energy literature as the first assessment of the impact of a national holistic area-based regeneration policy on fuel poverty.

The remainder of this paper is structured as follows. Section 2 provides an overview of fuel poverty in Northern Ireland and cites the relevant policies designed to address fuel poverty. The literature evaluating fuel poverty policies is explored in section 3 . The methods used to assess the impact of the NR strategy on fuel poverty in Northern Ireland are outlined in section 4 and the modelling results are documented in section 5 . Section 6 concludes with a synopsis of the strengths and limitations of the study, the findings of the investigation and implications for research and policy.

\section{Addressing fuel poverty in Northern Ireland}

The latest official figures on fuel poverty in Northern Ireland estimate that about 294,000 households, or about 42\% of the total, were fuel poor in 2011 (Northern Ireland Housing Executive, 2013). Whilst in 2001, the introduction of the Warm Homes Scheme (Department for Social Development, 2004; National Audit Office, 2008) contributed to reducing fuel poverty in Northern Ireland between 2001 and 2004 (from 27\% to 23\%), by 2006 the rate of fuel poverty had increased to $34 \%$ and then to $44 \%$ in 2009 mainly due to increases in the price of fuel and continued dependence on oil, electricity and solid fuel for heating in Northern Ireland (Northern Ireland Housing Executive, 2013). The 2011 House Condition Survey shows some progress in reducing the proportion in fuel poverty despite rising fuel prices largely as a result of significant investment in new energy efficiency measures such as heating conversions, insulation and double glazing by the Housing Executive in its own stock and also by the Warm Homes Scheme in private homes.

The 2001 UK Fuel Poverty Strategy (Department of the Environment, Transport and the Regions and Department of Trade and Industry, 2001), the 2004 Ending Fuel Poverty: A Strategy for Northern 
Ireland (Department for Social Development, 2004), and the 2011 Warmer Healthier Homes: a new Fuel Poverty Strategy for Northern Ireland (Department for Social Development, 2011a) are the main policy documents drafted to address fuel poverty in Northern Ireland. In particular, the 2004 Strategy aimed at eliminating fuel poverty in vulnerable households by 2010 , and in non-vulnerable households by 2016. It also indicated that no household in the social rented sector should suffer from fuel poverty by 2016 . The strategy recognised that the best way to tackle fuel poverty was through a partnership approach, which entails working with organisations that have an influence on income, fuel costs, energy provision and efficiency, and with organisations from the voluntary and community sector. The 2011 Warmer Healthier Homes strategy recognized that the 2001 strategy goal of eradicating fuel poverty by 2010 was set at a time of relatively low fuel prices and indicated that the new strategy needed to: remove energy inefficiency, achieve affordable energy for households, and build strong partnerships working across organisational and professional boundaries.

The central scheme for implementation of the fuel poverty strategy in Northern Ireland was the Warm Homes Scheme (Department for Social Development, 2004; National Audit Office, 2008), which was launched in 2001. Under this initiative, eligible households anywhere in the country could apply for a range of measures to upgrade the energy efficiency of their homes at a discounted or no cost. Walker et al. (2013) evaluated the success of Warm Homes using Geographic Information Systems mapping to compare targeting of the scheme at the small geographic area level with household need, assessed using a multi-dimensional fuel poverty risk index. The evaluators concluded that the policy may have had some impact on fuel poverty, but determined that targeting of the scheme was poor and the majority of retrofits were small-scale and unlikely to reduce fuel poverty. As a result, Walker et al. (ibid) suggested that fuel poverty policies could be better implemented using pre-emptive, area-based approaches. 


\section{Evaluating fuel poverty policies}

To date, the evaluations of policies on fuel poverty typically do not assess their performance according to 'official' definitions of fuel poverty such as the ten-percent definition - which states that households are fuel poor if they spend more than $10 \%$ of their income in fuel (Boardman, 1991) - or the Low Income High Cost measure, which states that a household is considered to be fuel poor if they must meet fuel costs that are above average (the national median level) and, were they to spend that amount, they would be left with a residual income below the official poverty line (Department of Energy and Climate Change, 2015). Instead, the fuel poverty literature has mostly examined impacts of policies on a range of alternate gauges such as subjective measures of ability to pay fuel bills, objective measures of indoor temperatures or energy consumption, and is dominated by a concern for health impacts (Critchley et al., 2007; Fowlie et al., 2015; Green and Gilbertson, 2008; Hong et al., 2009; Howden-Chapman et al., 2012, 2007; Liddell and Morris, 2010; C. R. Lloyd et al., 2008).

A review of the health effects of housing improvements (Fenwick et al., 2013) found six studies where energy efficiency improvements reduced fuel expenditures (Ambrose, 2000; Caldwell et al., 2001; Green and Gilbertson, 2008; Heyman et al., 2011; E. L. Lloyd et al., 2008; Shortt and Rugkåsa, 2007). However, in some cases, occupants also experienced rent increases after the improvements. Therefore, the net effect on household budgets and on fuel poverty was unknown. An uncontrolled before and after evaluation of the Warm Front scheme in England (Green and Gilbertson, 2008) found that, after receiving assistance, fewer recipients reported difficulties in paying fuel bills, but the overall daily fuel consumption increased. Even where retrofit schemes have proved successful in lowering energy use such as Howden-Chapman et al.'s (2007) randomised control trial of a domestic retrofit scheme in New Zealand, policy and literature recognise that refurbishments and building standards only partially address the causes of fuel poverty which 
require cross-cutting approaches (Department for Social Development, 2011a; Dubois, 2012; Roberts and Baker, 2006; Shortt and Rugkåsa, 2007; Walker et al., 2013).

The effect of area-based regeneration policies on fuel poverty has received little attention in the literature. The closest comparable study to consider the effect of urban regeneration on fuel poverty is reported by Curl and Kearns for the GoWell programme in Glasgow (Curl and Kearns, 2016). They found no evidence that fabric works or installation of modern central heating as part of the regeneration efforts affected occupants' experience of fuel payment difficulties.

This paper extends the evaluation of policies contributing to reducing fuel poverty through a unique investigation of the effect of urban regeneration using the official definition of fuel poverty in Northern Ireland.

\section{Methodology}

NR-backed assistance may influence the three primary interacting causes of fuel poverty for households: poor thermal efficiency of homes, low household income and the cost of fuel. Using the ten-percent definition for fuel poverty, the numerator is influenced by the thermal efficiency of homes and energy costs while the denominator concerns household income where,

(1) Fuel poor $=\frac{\text { Annual household expenditure on fuel }}{\text { Annual household income }}>10 \%$

NR interventions may affect both components of the definition through a number of different channels. Household income may be positively affected by economic uplift experienced in targeted communities where NR schemes foster enterprise and enable beneficiaries to improve their education, skills and access to employment. NR sponsored advice centres and resident associations 
may also play a role in improving incomes where they provide information on employment and training opportunities, help and guidance on money management and debt advice while ensuring eligible users avail of all benefits and welfare entitlement. The numerator, concerning fuel expenditures, may be indirectly affected by NR supported new housing and housing improvements, where more energy efficient dwellings moderate required fuel outlays. Additionally, advice centres encourage the take-up of various government-sponsored energy saving schemes such as the Warm Homes Scheme, as well as promoting general awareness of cheaper fuels (including oil buying clubs) and the benefits of insulation.

The NR policy offered an occasion for a natural experiment to assess the impact of a comprehensive regeneration strategy on fuel poverty. The thirty-six NRAs taken together exemplify the treatment group and were not randomly selected for intervention but rather earmarked by policymakers based on deprivation rankings. This assessment of impact draws on observational methods to facilitate an understanding of the impact of NR by comparing fuel poverty in NRAs to control areas to estimate the effect of the policy operating in a complex, dynamic environment.

\subsection{Data}

Observational secondary data from two high quality longitudinal datasets were exploited for the analysis. The Northern Ireland Household Panel Survey (NIHPS) ran from 2001 to 2008 providing eight waves of information for panel respondents and was replaced by the Understanding Society survey in 2009. Four waves of the Understanding Society survey, for the period 2009 to 2012, were available at the time of conducting this research. The NIHPS and Understanding Society surveys were merged using the person identifier information to construct a twelve year longitudinal panel of survey respondents, following the same individuals for the period 2001 to 2012 . This time horizon yielded respondent and household information for two years prior to NR instigation from 2003, and 
for a decade of policy application. The survey changeover did not provide a harmonious "household" identifier between the two surveys so the notion of a longitudinal household could not be explored. In wave one of the survey 3,458 respondents were interviewed, with $775(22.4 \%)$ respondents in NRAs.

\subsection{Intervention and control groups}

An access licence from the UK Data Service provided the respondents location at the geographic level of super output area. The Northern Ireland Neighbourhood Information Service provided a list of geographic small areas grouped to approximate NRA boundaries so an intervention group could be ascertained from a crosswalk of geographic identifiers. Therefore, the intervention group comprised all survey respondents residing in NRAs at the time of the survey, identified as NRA. A large control group consisting of all respondents living in policy-off super output areas in Northern Ireland were identified as the control group Non NRA (2,683 respondents in wave one). Using the 2005 multiple deprivation measure ranking of super output areas a further two control groups were constructed to facilitate a comparison of respondents living in similarly deprived environments (Northern Ireland Statistics and Research Agency, 2005). A narrow comparison group containing respondents living in the $25 \%$ most deprived non NRA super output areas was identified as Control 1. At wave one there were 243 respondents in Control 1. A second larger but marginally less deprived control group encompassing survey participants living in the $30 \%$ most deprived non NRA super output areas was categorised as Control 2. Control 2 had 384 respondents in the first wave of NIHPS.

\subsection{Measure of fuel poverty}

While the definition of fuel poverty in England has recently changed from the ten-percent definition to the Low Income High Cost measure (Department of Energy and Climate Change, 2015), the 
definition of fuel poverty in Northern Ireland's devolved fuel poverty strategies (Department for Social Development, 2011a, 2004) maintains Boardman's (1991) definition of a fuel poor household as one which must spend more than ten percent of income on fuel. Both the NIHPS and Understanding Society contained information on annual household expenditure on fuel and annual gross household income. Therefore, a dummy variable could be constructed which takes the value of one where the respondent lived in a household that spent more than ten percent of annual income on fuel, and zero otherwise.

\subsection{Statistical analysis}

Difference-in-difference is a statistical technique that attempts to estimate the impact of a change, for instance the introduction of a new policy, by simulating an experimental research design with observational study data. The pre- and post- policy change in fuel poverty for the NRA group relative to the control group(s) provides an estimate of the effect of NR on fuel poverty. The control group performance embodies the counterfactual, acting as a signal for what would have occurred in NRAs had the NR policy not been realised. Difference-in-difference approaches depend on the 'parallel trends' assumption where trends over time in fuel poverty are assumed to be equivalent in both the NRA and control group(s) in the absence of intervention. Other characteristics of control and intervention groups can differ but these differences are assumed to be fixed over time.

While NR was active, the main scheme implemented to reduce fuel poverty in Northern Ireland was the Warm Homes Scheme that ran during the whole length of the study period and targeted households both in NRAs and in non NRAs. NRAs were not singled out in the 2004 Northern Ireland fuel poverty strategy and there is no reason to believe that NRAs or controls were systematically treated differently under the fuel poverty strategy. In all, difference-in-difference presents a suitable method for the evaluation of the effect of NR on fuel poverty since it permits the estimation of the 
intervention effect where the intervention is not random, other external events occur when the policy is in force, and all potential confounders cannot be controlled for.

The following linear probability model ${ }^{1}$ is estimated to assess the impact of the NR policy on fuel poverty:

(2) $Y_{i t}=\beta_{0}+\beta_{1} N R_{i t}+\beta_{2} S_{i t}+\beta_{3}\left(N R_{i t} * S_{i t}\right)+\varepsilon_{i t}$

$$
\begin{aligned}
& Y_{i t}= \begin{cases}0 & \text { Not fuel poor } \\
1 & \text { Fuel poor }\end{cases} \\
& N R_{i t}= \begin{cases}0 & \text { Control group } \\
1 & N R A\end{cases} \\
& S_{i t}=\left\{\begin{array}{l}
0 \text { Before NR Strategy }(2001-2002) \\
1 \text { After NR Strategy }(2003-2012)
\end{array},\right.
\end{aligned}
$$

where $Y_{i t}$ represents whether the individual $i$ at time $t$ is living in fuel poverty or not; the dummy variable, $N R_{i t}$, is the intervention variable and specifies whether a survey participant resided in a NRA, or control at time of the interview. The three control groups are the previously described non NRA, Control 1 and Control 2 groups. The dummy variable, $S_{i t}$, takes on a value of one if the interview took place before the implementation of the NR Strategy and zero if it took place after the implementation. The difference-in-difference estimate is given by the interaction of $N R_{i t}$ and $S_{i t}$ and is the focal variable. It symbolizes the effect on fuel poverty of residing in an NRA while NR is operating when both dummies are equal to one. The $\beta_{s}$ are coefficients to be estimated, $\varepsilon_{i t}$ captures the residual error of the model. In particular, $\beta_{3}$, captures the effect of the differencein-difference estimate.

\footnotetext{
${ }^{1}$ The difference-in-difference regression on the dichotomous fuel poverty outcome is fitted as a linear probability model because of issues in interpreting interaction terms with non-linear models such as logit and probit (Athey and Imbens, 2006; Karaca-Mandic et al., 2012; Lechner, 2011).
} 
The estimated parameters can be expressed as:

(3) $\beta_{0}=E\left[Y_{i t} \mid N R_{i t}=0, S_{i t}=0\right]$

(4) $\beta_{1}=E\left[Y_{i t} \mid N R_{i t}=1, S_{i t}=0\right]-E\left[Y_{i t} \mid N R_{i t}=0, S_{i t}=0\right]$

(5) $\beta_{2}=E\left[Y_{i t} \mid N R_{i t}=0, S_{i t}=1\right]-E\left[Y_{i t} \mid N R_{i t}=0, S_{i t}=0\right]$

(6) $\beta_{3}=\left\{E\left[Y_{i t} \mid N R_{i t}=1, S_{i t}=1\right]-E\left[Y_{i t} \mid N R_{i t}=0, S_{i t}=1\right]\right\}-\left\{E\left[Y_{i t} \mid N R_{i t}=1, S_{i t}=\right.\right.$ $\left.0]-E\left[Y_{i t} \mid N R_{i}=0, S_{i t}=0\right]\right\}$

Difference-in-difference is a treatment on treated analysis where the difference-in-difference

estimator, $\beta_{3}$, in equation (6) gives the average treatment effect on the treatment group.

Next, model (2) is expanded by adding demographic and socioeconomic characteristics of the respondents, as well as the attributes of their home, represented by $X_{i t}$. The unrestricted difference-in-difference equation estimated is thus:

(7) $Y_{i t}=\beta_{0}+\beta_{1} N R_{i t}+\beta_{2} S_{i t}+\beta_{3}\left(N R_{i t} * S_{i t}\right)+\beta_{4} X_{i t}+\varepsilon_{i t}$ (Model 2)

The explanatory variables available from the survey included gender, age, education, employment status, sources of income, marital status, number of children, housing tenure, a variable capturing subjective financial situation and household attributes of dwelling type, central heating and main fuel type. ${ }^{2}$ The socio-demographic and economic characteristics of respondents are included to reduce confounding and the influence of these factors is of interest in energy research more widely (see Gaffney et al., 2015 for a review).

Heterogeneity in fuel poverty is explored by stratifying models 1 and 2 in equations (2) and (7) to investigate whether the difference-in-difference impact on fuel poverty altered for distinctive sub

\footnotetext{
2 The dataset covered detailed information on respondent's demographic and socioeconomic circumstances as well as attributes of their home such as dwelling type, central heating and main fuel type. Information on the presence of damp in the home and a question on whether the respondent keeps their home adequately warm were also recorded, though this information was only available for the NIHPS waves of the survey and not in Understanding Society. The responses to these questions are documented in the additional material file accompanying this paper (Table A-2, Figure A-1 and Figure A-2). There was also a question in both the NIHPS and Understanding Society surveys about the composition of the household (for example: lone pensioner, young couple, family with dependent children) which could be useful in explaining household energy expenditures. However, the categorisation of the different types of households could not be reconciled between the two surveys and thus could not be used as an explanatory variable.
} 
groups of the population. Therefore, subsample models are ran to explore the effect of NR on fuel poverty for different gender groups and for more fuel poor susceptible groups such as respondents receiving subsidies (e.g. low income, unemployment benefits), those retired and less well educated respondentsii. A subgroup of owner occupiers is also explored, since the Warm Homes scheme was promoted in NRAs for private households.

The difference-in-difference estimate relies on the parallel trends assumption. However, there is no 'real' test for the validity of parallel trends, because the trend in the treatment group after treatment is counterfactual. A 'placebo' estimation is also carried out as an exploratory test of the parallel trends assumption (Abadie et al., 2010; Basu et al., 2017); the pre-treatment trend in the control and treatment group is estimated in a regression which includes an interaction of time (i.e. survey wave) and treatment group status. Because there are only two waves of data available prior to the NR implementation and wave one is the comparison year, the parallel trends 'test' examines the significance of the interaction between wave two and treatment status. This variable should not be significant for the parallel trends assumption to hold. Ideally there should be at least three pretreatment periods to establish a clear trend; however this analysis could only draw on two preintervention periods.

The validity of the difference-in-difference results can also be affected by the potential for spillover effects where neighbouring policy-off areas avail of the opportunities afforded by NR. In the government commissioned evaluation of NR, stakeholders report there was a conscious effort to minimise leakage of NR projects beyond the NR boundaries (RSM McClurre Waters, 2014) and so the potential for fuel poverty benefits is expected to be limited to within the NR boundaries. In order to prevent contamination of the sample by migration patterns of respondents, those who move in or out of NRAs over the timeframe of the study were excluded from the analysis. Analysis was carried out in STATA version 13.1. 


\section{Empirical results}

\subsection{Descriptive statistics}

The personal characteristics of the study population groups in the first wave of the sample, prior to the NR policy implementation, are presented in Table 1 (statistical tests of differences between groups are included in the online additional material Table A-1). Respondents from NRAs were slightly younger, less well qualified, had lower levels of employment, differing marital status, more children, more likely to be on benefits and less likely to have investment income, had substantially less home ownership and less favourable perceived financial status than those of Non NRAs. The demographic and socioeconomic profiles of NRAs and similarly deprived Control 1 and 2 groups were homologous, though NRAs had more renters than both deprived groups and higher benefits than Control 1.

As documented in Table 2, NRA respondents were markedly less likely to live in detached homes compared to all other comparison groups. A quarter of NRA respondents (24.5\%) lived in households considered fuel poor in the first wave of the sample, $9 \%$ more than in Non NRAs (15.6\%) but only slightly higher than the deprived controls (Control $121.6 \%$, Control $222.2 \%$ ). Chi-squared tests of the difference in fuel poverty between the groups confirm the difference was not significant for the comparison of NRAs and similarly disadvantaged controls, though the fuel poverty difference was significant at the $1 \%$ level comparing NRAs and non NRAs (Additional material file Table A-1). One in seven (15.9\%) NRA respondents lived in damp accommodation, double the proportion for the rest of Northern Ireland (7.7\%) and treble that of Control 1 (5.0\%) and Control 2 (3.2\%). The prevalence of central heating was similar across all groups, though slightly lower in the disadvantaged controls. Oil was the dominant fuel type for all study groups though homes in NRAs were much more likely to use 
gas than the other groups. The desire to move house was strikingly greater among respondents in NRAs at $34.3 \%$ than for their counterparts in policy-off areas.

Table 1: Characteristics of study population at the first wave of sample ${ }^{\dagger}$

[Table 1]

Table 2: Household characteristics of study population at the first wave of sample ${ }^{\dagger}$

[Table 2]

As depicted in Figure 1 fuel poverty declined over time for NRA respondents up to wave seven of the survey but spiked in waves eight, ten and eleven. The time trend in fuel poverty for similarly deprived control groups closely matched the intervention group, however in the final wave, twelve, fuel poverty soared for these disadvantaged controls. Fuel poverty was less volatile for the Non NRA cohort, though the overall trend was upward with a hike in wave eight and moderate climbs in waves ten and eleven. The mean annual household fuel expenditure, also displayed under Figure 1, demonstrates that there was a consistent increase in fuel expenditures across all groups with NRAs spending the least in absolute terms. A slightly widened gap emerged in fuel expenditures in the later years of the survey where fuel expenditures for survey respondents in Non NRAs, Control 1 and to a lesser extent Control 2 grew slightly faster than for those in NRAs. The upsurge in fuel spend in wave eight followed by a dip reflects the price of oil peaking at $\$ 145$ a barrel in July 2008 and the subsequent sharp decline in oil prices coinciding with the financial crisis and recession of 2008-2009. Figure 1 also shows that household incomes were consistently lower in NRAs than all other groups, though these exhibited steady sustained growth over the survey timeframe.

Figure 1: Fuel poverty and definition components over the study period by groups: 2001 (wave 1) - 2012

(wave 12)

[Figure 1] 


\subsection{Difference-in-difference models results}

The results of the difference-in-difference models 1 and 2 for fuel poverty in NRAs compared to the three control groups are presented in Table 3. Prior to NR, the probability of being in a fuel poor household in the crude model (model 1) was 7.5\% significantly higher in NRAs than in Non NRAs. When the demographic, socioeconomic variables and the attributes of the homes of respondents were accounted for, this gap reduced to $2.9 \%$, statistically significant at the $5 \%$ conventional significance level. A 4.4\% difference between the NRA and the non NRA control group in the followup NR period remained statistically significant in model 1 . However, in the unrestricted model 2, at follow-up the difference sign changed to negative, indicating that, when the explanatory variables were accounted for, NRAs realised lower fuel poverty than the rest of the country. This follow-up difference was small in magnitude at $0.1 \%$ and not statistically significant. According to the difference-in-difference estimate, accounting for the characteristics of respondents, NR contributed to a statistically significant reduction in the probability that respondents in NRAs were fuel poor by a magnitude of $3.0 \%(95 \% \mathrm{Cl}-5.7 \%$ to $-0.3 \%)$ compared to the rest of Northern Ireland.

Other explanatory variables implied that having a tertiary level education as opposed to no qualifications was associated with a relief in a respondent's probability of being fuel poor, all other factors held constant. All non-employed states had a significant positive influence on being in a fuel poor household. Being married as opposed to single reduced the chance of being fuel poor while marital breakdown and widowhood increased the likelihood. Receiving benefit payments was not associated with fuel poverty, while having a pension or investment income reduced the likelihood of being in a fuel poor household. When considering owner occupation, private renting was positively linked to being in a fuel poor household. As one might expect, a more comfortable perceived financial situation was connected with lower fuel poverty. Residing in a detached home, as opposed 
to a terraced dwelling, accentuated the likelihood of belonging to a fuel poverty household, but having a semi-detached home or flat was less associated with being fuel poor. Using gas as the principal fuel type eased fuel poverty relative to oil-dependence, while relying on solid-fuel promoted fuel poverty and central heating was associated with fuel poverty mitigation.

Model 1 explains little of the variation in fuel poverty. The inclusion of socio-demographic and home variables improved the explanatory power of the models $\left(R^{2}=0.14\right)$. Other elements which were not captured in the survey may have greater influences on fuel poverty such as the energy efficiency rating of homes, energy practices of the household etc.

Turning to the comparison of NRAs and similarly deprived controls, Table 3 shows that pre-NR the probability of being in a fuel poor household in NRAs was higher than the correspondingly deprived control groups. The gap was not statistically significant in the case of the crude models but when information on respondents and their homes was accounted for, the difference was significant. At follow-up the probability of being in a fuel poor household was reduced for the NR group more than the controls. The difference-in-difference estimate indicates a $4.7 \%(95 \% \mathrm{Cl}-9.4 \%$ to $-0.1 \%)$ decline in fuel poverty witnessed for NRAs relative to the closely matched Control 1 deprivation group in the unrestricted model 2 . However, the decline in fuel poverty was not of a sufficient magnitude for the difference-in-difference estimate to achieve statistical significance in the other models. By and large, the other explanatory variables in the comparison of analogously disadvantaged comparison areas had a similar effect on fuel poverty as compared with all other neighbourhoods in Northern Ireland. However, graduate education and other non-employed states were not significantly associated with fuel poverty when NRAs were compared with correspondingly underprivileged neighbourhoods. Moreover, other tenure arrangements than home ownership were associated with a reduced likelihood of fuel poverty in the comparison of NRAs with similarly deprived areas. 
The results of the exploratory "placebo test" of the parallel trends assumption comparing NRAs and the three controls revealed that the interaction between the intervention dummy, NR, and the preintervention time period, wave two, did not have a significant effect on fuel poverty (presented in additional material Table A-3). Therefore it can be inferred that the parallel trends assumption was upheld.

Table 3: Difference-in-difference regression estimation results for fuel poverty [Table 3]

\subsection{Difference-in-difference models: heterogeneous characteristics of respondents}

The stratified difference-in-difference estimates for subgroups of the sample are presented in Table 4. Compared to all policy-off areas there was some evidence of a slightly greater reduction in fuel poverty among females $(-4.5 \%)$ in renewal areas relative to males $(-4.3 \%)$, though this result did not remain robust for the models that include respondents' socioeconomic and demographic variables and respondents' home characteristics. Less highly educated groups experienced a robust significant reduction $(-4.2 \%)$ in the probability of experiencing fuel poverty as a result of NR comparing NRAs and all non-intervention areas. There was some evidence that retired groups experienced a $6.1 \%$ reduction in fuel poverty as a result of NR compared to the rest of Northern Ireland, though this was only significant at the $10 \%$ marginal statistical significance level. Similarly, there was tentative evidence that groups receiving benefits in NRAs compared to all policy-off areas witnessed abatement in the probability of fuel poverty of $3.6 \%$ as a result of NR.

When females in NRAs were compared with their counterparts in the similarly deprived Control 1 group, the reduction in fuel poverty did not achieve statistical significance. However, the unrestricted model for males indicates that males in NRAs benefitted from a $7.5 \%$ decline in fuel poverty compared to those in Control 1. A 7.3\% relief in fuel poverty was observed among owner 
occupying groups in NRAs compared to those in Control 1 . There was no statistically discernible effect of NR on fuel poverty in NRAs compared to Control 2 at the aggregate or subgroup level. Table 4: Subgroup results for fuel poverty

[Table 4] 


\section{Conclusion and Policy Implications}

This study is the first to explore the effect of targeted regeneration assistance to socio-economically marginalised and physically neglected areas on fuel poverty. The assessment employs a quasiexperimental difference-in-difference econometric technique to estimate the effect of the policy. An advantage of the difference-in-difference method is that it permits, and controls for, the baseline differences in fuel poverty observed between the intervention and control groups. Three different control groups afforded an exploration of the counterfactual. Panel data was used where the same respondents were followed-up over a twelve year period. The survey information permitted the prevailing measure of fuel poverty, the ten-percent definition, to be constructed. The source survey was also well-endowed with information on respondent's personal circumstances and that of their homes, which permitted control for a range of confounding factors.

The empirical findings from the NR natural experiment lend support to the theory that multifaceted urban regeneration policy may be an effective vehicle in tackling fuel poverty in areas earmarked for support. Improving the economic prosperity of residents in communities which have higher concentrations of fuel poor households and local championing of resources may combine to remedy inequalities in fuel poverty between disparate groups. While the estimated reduction in fuel poverty attributable to NR is modest, this is a commendable achievement given the difficult economic background which coincided with the operational period of the policy.

Other wider benefits may be realised for NR residents who experienced alleviation in fuel poverty where more affordable warmth enhances quality of life, contributes to health and wellbeing and reduces health inequalities (Threlfall, 2011). The UK Health Forum (2014) acknowledged that tackling fuel poverty has the potential to save lives, reduce pressure on the health system as well as contribute to the government's fuel poverty and climate change mitigation targets. 
In terms of the policy implications of this work, it is noted that fuel poverty is a particularly obstinate issue in Northern Ireland and has proved difficult to relieve by existing policies which focus on energy efficiency (Walker et al., 2013). The findings of this research endorse social and economic renewal policies as a complementary means to strengthen government efforts to tackle fuel poverty. Furthermore, the additional resources, staff and community infrastructure supported by area-based urban regeneration initiatives could act as a conduit for the proactive, area based approaches to targeting of energy efficiency measures by geographic mapping proposed by Walker et al. (2013). Local regeneration partnership boards and on the ground personnel also provide a natural platform for 'decentralised identification' of households at risk of fuel poverty as advocated by Dubois (2012), where agents with good knowledge of the local situation and households identify those which may stand to benefit from fuel poverty assistance.

The analysis could have benefited from information that was not captured in the survey questionnaire such as a measure of the energy efficiency of dwellings, for example a SAP (Standard Assessment Procedure) rating to help explain fuel expenditures. In 2014 the Innovation Panel of Understanding Society explored the feasibility of measuring household energy consumption where household meter-readings were taken, therefore better information for research may become available in the future (Al et al., 2014). The changes to questions in the transition of the survey from NIPHS to Understanding Society also inhibited investigation of some potentially interesting variables such as the relationship between fuel poverty and the composition of the household. The secondary nature of the data also means that it was not possible to assess the degree of exposure of respondents to NR activities or whether respondents actively participated in NR fuel poverty initiatives. Qualitative interviews with NR coordinators and those executing local schemes on the ground were not conducted as part of this study but could help explain how NR was instrumental in reducing fuel poverty in assisted areas. 
It is also worth noting that over the twelve year survey duration in Northern Ireland the sample was subject to attrition of $55 \%$ between wave one and wave twelve. To check the robustness of the generated results the regression analysis was also performed using inverse probability weighting to account for attrition from observable characteristics. The estimates of the effect of NR on fuel poverty using the weighted sample did not significantly differ from the unweighted sample. The results of the weighting are presented in the additional material file (Table A-4).

This study suggests possible pathways by which fuel poverty may be affected by area-based initiatives which aim to regenerate distressed neighbourhoods. Better theory must be developed to aid our understanding of and empirically investigate how changes in community, social, economic and physical conditions shape the risk profile and occurrence of fuel poverty. Qualitative research involving residential beneficiaries of regeneration programmes, as well as with the implementers of such schemes, could shed light on the mechanisms of change. 
Funding: This research did not receive any specific grant from funding agencies in the public, commercial, or not-for-profit sectors.

Note on Figure 1: Figure 1 contains three images:

1. Respondents living in fuel poor households

2. Mean annual household expenditure on fuel ( $€$ )

3. Mean annual household income $(f)$

The figure legend for all 3 images is: NRA, Non NRA, Control 1, Control 2. 


\section{REFERENCES}

Abadie, A., Diamond, A., Hainmueller, J., Badie, A.A., lamond, A.D., Ainmueller, J.H., 2010. Synthetic Control Methods for Comparative Case Studies: Estimating the Effect of California' s Tobacco Control Program. J. Am. Stat. Assoc. 105, 493-505.

Al, T., Allum, C.N., Auspurg, K., Blake, M., Crossley, T., Ardenne, J.D., lacovou, M., Jäckle, A., Kaminska, O., Nicoletti, C., Oldfield, Z., Pudney, S., Uhrig, S.C.N., Winter, J., 2014. Understanding Society Innovation Panel Wave 6: Results from Methodological Experiments. Underst. Soc. Work. Pap. Ser.

Ambrose, P., 2000. A drop in the ocean; the health gain from the Central Stepney SRB in the context of national health inequalities. The Health and Social Policy Research Centre, University of Brighton, London.

Athey, S., Imbens, G., 2006. Identification and inference in nonlinear difference-in-differences models. Econometrica 74, 431-497.

Atkinson, R., 1999. Discourses of Partnership and Empowerment in Contemporary British Urban Regeneration. Urban Stud. 36, 59-72.

Balfour, R., Allen, J., 2014. Local action on health inequalities: Fuel poverty and cold home-related health problems. Public Health England, London.

Basu, S., Meghani, A., Siddiqi, A., 2017. Evaluating the Health Impact of Large-Scale Public Policy Changes: Classical and Novel Approaches. Annu. Rev. Public Health 38, 351-70.

Boardman, B., 1991. Fuel poverty: from cold homes to affordable warmth. Belhaven Press, London.

Braubach, M., Ferrand, A., 2013. Energy efficiency, housing, equity and health. Int. J. Public Health $58,331-332$. 
Caldwell, J., Mc Gowan, S., Mc Phail, J., Mc Rae, C., Morris, G., Murray, K., 2001. Glasgow warm homes study: final report. Glasgow City Council Housing Services, Glasgow.

Critchley, R., Gilbertson, J., Grimsley, M., Street, H., 2007. Living in cold homes after heating improvements: Evidence from Warm-Front, England's Home Energy Efficiency Scheme. Appl. Energy 84, 147-158.

Curl, A., Kearns, A., 2016. Housing improvements, fuel payment difficulties and mental health in deprived communities. Int. J. Hous. Policy 1-27.

Department for Social Development, 2003. Neighbourhood Renewal - People and Place. Department for Social Development, Belfast.

Department for Social Development, 2004. Ending Fuel Poverty: A Strategy for Northern Ireland. Department for Social Development, Belfast.

Department for Social Development, 2011a. Warmer Healthier Homes. Department for Social Development, Belfast.

Department for Social Development, 2011b. People and Place Renewal Mid-Term Review. Department for Social Development, Belfast.

Department of Energy and Climate Change, 2015. Cutting the cost of keeping warm - a fuel poverty strategy for England. Department of Energy and Climate Change, London.

Department of the Environment, Transport and the Regions, Department of Trade and Industry, 2001. UK Fuel Poverty Strategy. Department of Trade and Industry, London.

Downpatrick Neighbourhood Renewal Partnership, 2010. Downpatrick Neighbourhood Renewal Partnership Action Plan: April 2007 - March 2010. Department for Social Development, Belfast.

Dubois, U., 2012. From targeting to implementation: The role of identification. Energy Policy 49, 
107-115.

Fenwick, E., Macdonald, C., Thomson, H., 2013. Economic analysis of the health impacts of housing improvement studies: a systematic review. J. Epidemiol. Community Health 67, 835-45.

Foley, P., Martin, S., 2000. A new deal for the community? Public participation in regeneration and local service delivery. Policy Polit. 28, 479-492.

Fowlie, M., Greenstone, M., Wolfram, C., 2015. Do Energy Efficiency Investments Deliver? Evidence from the Weatherization Assistance Program. NBER Work. Pap. No. 21331 1-56.

Gaffney, C., Lennon, B., Connor, P.O., Dunphy, N., 2015. Survey of sociodemographic data on energy practices. University College Cork, Cork.

Greater Falls Neighbourhood Renewal Partnership, 2013. Greater Falls Neighbourhood Renewal Area Annual Report 2012/2013. Department for Social Development, Belfast.

Green, G., Gilbertson, J., 2008. Warm Front Better Health. Centre for Regional and Social Research, Sheffield.

Heyman, B., Harrington, B., Heyman, A., Energy, T.N., 2011. A Randomised Controlled Trial of an Energy Efficiency Intervention for Families Living in Fuel Poverty. Hous. Stud. 26, 117-132.

Hong, S.H., Gilbertson, J., Oreszczyn, T., Green, G., Ridley, I., Study, F., 2009. A field study of thermal comfort in low-income dwellings in England before and after energy efficient refurbishment. Build. Environ. 44, 1228-1236.

Howden-Chapman, P., Matheson, A., Crane, J., Viggers, H., Cunningham, M., Blakely, T., Cunningham, C., Woodward, A., Saville-, K., Dea, D.O., Kennedy, M., Baker, M., Waipara, N., Chapman, R., Davie, G., 2007. Effect of insulating existing houses on health inequality: cluster randomised study in the community. Br. Med. J. 334. 
Howden-Chapman, P., Viggers, H., Chapman, R., O’Sullivan, K., Telfar Barnard, L., Lloyd, B., 2012. Tackling cold housing and fuel poverty in New Zealand: A review of policies, research, and health impacts. Energy Policy 49, 134-142.

Karaca-Mandic, P., Norton, E.C., Dowd, B., 2012. Interaction Terms in Nonlinear Models. Health Serv. Res. 47, 255-274.

Lechner, M., 2011. The Estimation of Causal Effects by Difference-in-Difference Methods. Found. Trends Econom. 4, 165-224.

Liddell, C., Morris, C., 2010. Fuel poverty and human health: A review of recent evidence. Energy Policy 38, 2987-2997.

Lloyd, C.R., Callau, M.F., Bishop, T., Smith, I.J., 2008. The efficacy of an energy efficient upgrade program in New Zealand. Energy Build. 40, 1228-1239.

Lloyd, E.L., Mccormack, C., Mckeever, M., Syme, M., 2008. The effect of improving the thermal quality of cold housing on blood pressure and general health: a research note. J. Epidemiol. Community Health 62, 793-798.

Marmot, M., 2011. The Health Impacts of Cold Homes and Fuel Poverty. Friends of the Earth and Marmot Review Team, London.

Meegan, R., Mitchell, A., 2001. "It's Not Community Round Here, It's Neighbourhood": Neighbourhood Change and Cohesion in Urban Regeneration Policies. Urban Stud. 38, 21672194.

National Audit Office, 2008. Warm Homes: Tackling Fuel Poverty. The Stationary Office, Belfast. Northern Ireland Housing Executive, 2013. Northern Ireland House Condition Survey 2011 - Main Report. Northern Ireland Housing Executive, Belfast. 
Northern Ireland Statistics and Research Agency, 2005. Multiple Deprivation Measure 2005. Northern Ireland Statistics and Research Agency, Belfast.

Roberts, S., 2008. Energy, equity and the future of the fuel poor. Energy Policy 36, 4471-4474.

Roberts, S., Baker, W., 2006. Tackling fuel poverty at local and regional level: Opportunities to deliver action and policies to stimulate success. Centre for Sustainable Energy, Bristol.

RSM McClurre Waters, 2014. Neighbourhood Renewal A Final Evaluation. Department for Social Development, Belfast.

Shortt, N., Rugkåsa, J., 2007. "The walls were so damp and cold" fuel poverty and ill health in Northern Ireland: results from a housing intervention. Heal. Place 13, 99-110.

Social Exclusion Unit, 2001. A new commitment to neighbourhood renewal: national strategy action plan. Social Exclusion Unit, London.

Strabane Neighbourhood Renewal Partnership, 2012. Strabane Neighbourhood Renewal Area Annual Report 2012/13 year. North West Neighbourhood Renewal Development Office, Londonderry.

Threlfall, A., 2011. Understanding the costs and benefits of fuel poverty interventions: A pragmatic economic evaluation from Greater Manchester. Greater Manchester Public Health Practice Unit, Salford.

Triax Neighbourhood Renewal Partnership Board, 2011. Triax Neighborhood Partnership Board Action Plan 2011. Londonderry.

UK Health Forum, 2014. Fuel poverty how to improve health and wellbeing through action on affordable warmth. UK Health Forum, London.

Walker, G., Day, R., 2012. Fuel poverty as injustice: Integrating distribution, recognition and 
procedure in the struggle for affordable warmth. Energy Policy 49, 69-75.

Walker, R., Liddell, C., Mckenzie, P., Morris, C., 2013. Evaluating fuel poverty policy in Northern Ireland using a geographic approach. Energy Policy 63, 765-774.

Webber, P., Gouldson, A., Kerr, N., 2015. The impacts of household retrofit and domestic energy efficiency schemes: A large scale, ex post evaluation. Energy Policy 84, 35-43.

Wilkinson, P., Smith, K.R., Joffe, M., Haines, A., 2007. A global perspective on energy: health effects and injustices. Lancet 370, 965-978. 
Tables

The effect of area based urban regeneration policies on fuel poverty: evidence from a natural experiment in Northern I reland.

Table 5: Characteristics of study population at the first wave of sample ${ }^{+}$

\begin{tabular}{|c|c|c|c|c|c|}
\hline \multicolumn{2}{|c|}{ Characteristics of respondents } & NRA & Non NRA & Control 1 & Control 2 \\
\hline \multicolumn{2}{|l|}{$\mathrm{N}$} & 654 & 2,408 & 222 & 342 \\
\hline \multicolumn{2}{|l|}{ Female (\%) } & 59.6 & 57.2 & 56.8 & 58.5 \\
\hline \multicolumn{2}{|l|}{ Age (mean) } & 44.9 & 46.3 & 44.4 & 46.9 \\
\hline \multirow{6}{*}{$\begin{array}{l}\text { Education } \\
\text { (\%) }\end{array}$} & Degree & 5.8 & 11.8 & 4.1 & 4.7 \\
\hline & Other higher & 8.9 & 15.1 & 13.1 & 11.4 \\
\hline & A Levels & 9.8 & 11.2 & 9.5 & 9.4 \\
\hline & GCSE & 20.6 & 20.3 & 21.6 & 19.3 \\
\hline & Other qualification & 9.0 & 10.7 & 7.7 & 8.2 \\
\hline & No qualifications & 45.9 & 30.9 & 44.1 & 47.1 \\
\hline \multirow{7}{*}{$\begin{array}{l}\text { Jobs status } \\
\text { (\%) }\end{array}$} & Self-employed/employed & 36.7 & 54.4 & 41.9 & 41.5 \\
\hline & Unemployed & 8.9 & 4.2 & 7.7 & 6.4 \\
\hline & Retired & 20.6 & 20.0 & 17.6 & 22.5 \\
\hline & Family care & 15.1 & 10.2 & 16.2 & 14.3 \\
\hline & Full time student & 4.0 & 4.5 & 5.4 & 3.8 \\
\hline & Long term sick & 11.5 & 5.6 & 10.8 & 10.5 \\
\hline & Non-paid employment & 3.2 & 1.2 & 0.5 & 0.9 \\
\hline \multirow{4}{*}{$\begin{array}{l}\text { Marital } \\
\text { status (\%) }\end{array}$} & Single & 30.6 & 24.9 & 36.9 & 33.6 \\
\hline & Married/Civil Partnership & 48.5 & 59.8 & 42.3 & 45.9 \\
\hline & Separated/Divorced & 12.1 & 7.4 & 11.3 & 10.5 \\
\hline & Widowed & 8.9 & 7.9 & 9.5 & 9.9 \\
\hline \multicolumn{2}{|c|}{ Number of children (mean) } & 0.7 & 0.6 & 0.6 & 0.6 \\
\hline \multirow[t]{3}{*}{ Tenure (\%) } & Owner occupier & 52.9 & 79.7 & 67.1 & 66.1 \\
\hline & Social rent & 36.4 & 12.2 & 27.0 & 26.6 \\
\hline & Private rent/ Other tenure & 10.7 & 8.1 & 5.9 & 7.3 \\
\hline \multicolumn{2}{|c|}{ Benefits (\%) } & 67.4 & 55.9 & 59.9 & 65.2 \\
\hline \multicolumn{2}{|c|}{ Pension (\%) } & 10.6 & 13.3 & 9.9 & 11.4 \\
\hline \multicolumn{2}{|c|}{ Investment income (\%) } & 13.3 & 24.6 & 14.0 & 14.0 \\
\hline \multirow{5}{*}{$\begin{array}{l}\text { Subjective } \\
\text { financial } \\
\text { status (\%) }\end{array}$} & Living comfortably & 21.4 & 33.0 & 21.6 & 24.6 \\
\hline & Doing alright & 32.6 & 35.9 & 34.2 & 35.1 \\
\hline & Getting by & 35.3 & 24.1 & 33.3 & 30.1 \\
\hline & Finding it quite difficult & 7.8 & 4.9 & 5.9 & 6.4 \\
\hline & Finding it very difficult & 2.9 & 2.1 & 5.0 & 3.8 \\
\hline
\end{tabular}

${ }^{\dagger}$ The sample employed in modelling excludes residents who migrate in/out of NRAs over the study period and observations with missing values. 
Table 6: Household characteristics of study population at the first wave of sample ${ }^{\dagger}$

\begin{tabular}{|c|c|c|c|c|c|}
\hline \multicolumn{2}{|c|}{ Household characteristics } & \multirow{2}{*}{$\begin{array}{l}\text { NRA } \\
654\end{array}$} & \multirow{2}{*}{$\begin{array}{l}\text { Non NRA } \\
2,408\end{array}$} & \multirow{2}{*}{$\begin{array}{l}\text { Control } 1 \\
222\end{array}$} & \multirow{2}{*}{$\begin{array}{l}\text { Control } 2 \\
342\end{array}$} \\
\hline $\mathrm{N}$ & & & & & \\
\hline Dwelling & Detached & 10.9 & 48.4 & 39.2 & 38.0 \\
\hline type & Semi Detached & 22.8 & 27.1 & 15.3 & 15.2 \\
\hline \multirow[t]{2}{*}{ (\%) } & Terraced & 57.7 & 20.6 & 36.5 & 38.6 \\
\hline & Flat/other dwelling & 8.7 & 3.9 & 9.0 & 8.2 \\
\hline \multicolumn{2}{|c|}{ Fuel poor (\%) } & 24.5 & 15.6 & 21.6 & 22.2 \\
\hline \multicolumn{2}{|c|}{ Mean annual household fuel spend ( $f$ ) } & 948 & 1,076 & 1,099 & 1,047 \\
\hline \multicolumn{2}{|c|}{ Mean annual household income $(f)$} & 19,232 & 26,326 & 21,709 & 20,800 \\
\hline \multicolumn{2}{|c|}{${ }^{*}$ Living in damp home (\%) } & 15.9 & 7.5 & 5.0 & 3.2 \\
\hline \multicolumn{2}{|c|}{ Home has central heating (\%) } & 86.7 & 87.9 & 84.7 & 85.4 \\
\hline \multirow{4}{*}{$\begin{array}{l}\text { Heating } \\
\text { fuel type } \\
\text { (\%) }\end{array}$} & Gas & 7.8 & 1.5 & 2.3 & 2.1 \\
\hline & Electricity & 8.1 & 5.3 & 12.2 & 12.9 \\
\hline & Oil & 54.6 & 72.1 & 57.2 & 57.6 \\
\hline & Solid fuel/other & 16.2 & 9.0 & 13.1 & 12.9 \\
\hline \multicolumn{2}{|c|}{ Would like to move house (\%) } & 34.3 & 22.8 & 25.7 & 26.3 \\
\hline \multicolumn{6}{|c|}{$\begin{array}{l}{ }^{+} \text {The sample employed in modelling excludes residents who migrate in/out of NRAs and observations } \\
\text { with missing values. } \\
{ }^{\ddagger} \text { Question not asked in waves } 9-12 \text { (Understanding Society) }\end{array}$} \\
\hline
\end{tabular}


Table 7: Difference-in-difference regression estimation results for fuel poverty

\begin{tabular}{|c|c|c|c|c|c|c|}
\hline & \multicolumn{2}{|c|}{ NRA v Non NRA $(\mathrm{N}=25,236)$} & \multicolumn{2}{|c|}{ NRA v Control $1(\mathrm{~N}=6,731)$} & \multicolumn{2}{|c|}{ NRA v Control $2(\mathrm{~N}=7,632)$} \\
\hline & Model 1 & Model 2 & Model 1 & Model 2 & Model 1 & Model 2 \\
\hline \multicolumn{7}{|l|}{ Pre-NR (2001-2002) } \\
\hline Control & 0.143 & 0.096 & 0.182 & 0.101 & 0.188 & 0.107 \\
\hline NRA & 0.218 & 0.124 & 0.218 & 0.145 & 0.218 & 0.144 \\
\hline \multirow{2}{*}{ Pre-NR difference } & $0.075^{* * *}$ & $0.029 * *$ & 0.036 & $0.044 * *$ & 0.030 & $0.037 * *$ \\
\hline & $(0.013)$ & $(0.012)$ & $(0.023)$ & $(0.021)$ & $(0.020)$ & $(0.018)$ \\
\hline \multicolumn{7}{|l|}{ NR (2003-2012) } \\
\hline Control & 0.132 & 0.087 & 0.159 & 0.112 & 0.150 & 0.094 \\
\hline NRA & 0.163 & 0.086 & 0.163 & 0.110 & 0.163 & 0.108 \\
\hline \multirow{2}{*}{ NR difference } & $0.031 * * *$ & -0.001 & 0.004 & -0.003 & 0.013 & 0.014 \\
\hline & $(0.007)$ & $(0.006)$ & $(0.011)$ & $(0.011)$ & $(0.010)$ & $(0.009)$ \\
\hline \multirow{3}{*}{$\begin{array}{l}\text { Difference-in- } \\
\text { Difference }[95 \% \mathrm{Cl}]\end{array}$} & $-0.044 * * *$ & $-0.030 * *$ & -0.032 & $-0.047 * *$ & -0.017 & -0.023 \\
\hline & $(0.015)$ & $(0.014)$ & $(0.025)$ & $(0.024)$ & $(0.022)$ & $(0.021)$ \\
\hline & [-0.074 to -0.015$]$ & [-0.057 to -0.003$]$ & [-0.081 to 0.018$]$ & [-0.094 to -0.001$]$ & {$[-0.061$ to 0.026$]$} & [-0.064 to 0.017$]$ \\
\hline $\mathrm{R}^{2}$ & 0.00 & 0.14 & 0.00 & 0.15 & 0.00 & 0.15 \\
\hline Female & & -0.001 & & 0.013 & & $0.015^{*}$ \\
\hline Age & & $0.002 * * *$ & & $0.001 * * *$ & & $0.001 * * *$ \\
\hline \multicolumn{7}{|c|}{ Education - base no qualifications } \\
\hline Degree & & $-0.029 * * *$ & & -0.012 & & -0.009 \\
\hline Other tertiary & & $-0.026 * * *$ & & $-0.032 * *$ & & $-0.032 * *$ \\
\hline A-level & & $-0.013^{*}$ & & -0.020 & & -0.019 \\
\hline GCSE & & -0.003 & & 0.000 & & 0.002 \\
\hline Other qualification & & $-0.024 * * *$ & & $-0.075 * * *$ & & $-0.064 * * *$ \\
\hline \multicolumn{7}{|c|}{ Employment status - base in employment } \\
\hline Unemployed & & $0.172 * * *$ & & $0.216^{* * *}$ & & $0.204^{* * *}$ \\
\hline Retired & & $0.135^{* * *}$ & & $0.087^{* * *}$ & & $0.089 * * *$ \\
\hline Family care & & $0.119 * * *$ & & $0.144^{* * *}$ & & $0.142 * * *$ \\
\hline Full time student & & $0.040 * * *$ & & $0.059 * * *$ & & $0.054^{* * *}$ \\
\hline Long term sick & & $0.123 * * *$ & & $0.126 * * *$ & & $0.119 * * *$ \\
\hline Other non-employed & & $0.063^{* * *}$ & & 0.038 & & 0.035 \\
\hline \multicolumn{7}{|c|}{ Marital status - base single } \\
\hline Married/Civil Partner & & $-0.064 * * *$ & & $-0.066 * * *$ & & $-0.063 * * *$ \\
\hline Separated/Divorced & & $0.059 * * *$ & & $0.042^{* *}$ & & $0.054 * * *$ \\
\hline Widow & & $0.083^{* * *}$ & & $0.115^{* * *}$ & & $0.129 * * *$ \\
\hline Number of children & & -0.002 & & $-0.011 * *$ & & $-0.012 * *$ \\
\hline Benefits & & 0.006 & & 0.000 & & 0.003 \\
\hline Pension & & $-0.079 * * *$ & & $-0.055^{* * *}$ & & $-0.048 * * *$ \\
\hline Investment income & & $-0.015^{* * *}$ & & $-0.023 * *$ & & $-0.017^{*}$ \\
\hline \multicolumn{7}{|c|}{ Tenure type - base owner occupier } \\
\hline Social rent & & 0.005 & & -0.004 & & 0.002 \\
\hline Private rent & & $0.076 * * *$ & & $0.066 * * *$ & & $0.064 * * *$ \\
\hline \multicolumn{7}{|c|}{ Subjective financial status - base getting by } \\
\hline Living comfortably & & $-0.087^{* * *}$ & & $-0.101 * * *$ & & $-0.099 * * *$ \\
\hline Doing alright & & $-0.054 * * *$ & & $-0.060 * * *$ & & $-0.061 * * *$ \\
\hline Quite difficult & & $0.043 * * *$ & & $0.092 * * *$ & & $0.080 * * *$ \\
\hline Very difficult & & $0.089 * * *$ & & $0.193^{* * *}$ & & $0.165^{* * *}$ \\
\hline \multicolumn{7}{|c|}{ Dwelling type - base terrace house } \\
\hline Detached & & $0.038 * * *$ & & $0.079 * * *$ & & $0.085^{* * *}$ \\
\hline Semi-detached & & $-0.013^{* *}$ & & -0.004 & & -0.007 \\
\hline Flat/other & & $-0.040 * * *$ & & $-0.040^{*}$ & & -0.029 \\
\hline \multicolumn{7}{|l|}{ Fuel type - base oil } \\
\hline Electricity & & $-0.030 * *$ & & 0.001 & & -0.008 \\
\hline Gas & & $-0.030 * * *$ & & $-0.027^{* *}$ & & $-0.028 * *$ \\
\hline Solid fuel/other & & $0.096 * * *$ & & $0.149 * * *$ & & $0.147^{* * *}$ \\
\hline
\end{tabular}


Central heating

$-0.033^{* * *}$

$-0.037^{* *}$

$-0.031^{*}$

${ }^{*}$ Significant at p $0.1 ;{ }^{* *}$ at $\mathrm{p} .05 ;{ }^{* * *}$ at $\mathrm{p} 0.01$. Robust standard errors (in parentheses).

Table 8: Subgroup results for fuel poverty (only subgroups demonstrating statistically significant results displayed)

\begin{tabular}{|c|c|c|c|c|c|c|c|}
\hline \multirow[b]{2}{*}{ Subgroup $\S$} & \multirow[b]{2}{*}{$\mathrm{n}$} & \multicolumn{3}{|c|}{ Model 1} & \multicolumn{3}{|c|}{ Model $2 \pi$} \\
\hline & & $\begin{array}{c}\text { Pre-NR } \\
2001-2002\end{array}$ & $\begin{array}{c}\text { NR } \\
2003-2012\end{array}$ & $\begin{array}{c}\text { Difference-in- } \\
\text { difference } \\
{[95 \% \mathrm{Cl}]}\end{array}$ & $\begin{array}{c}\text { Pre-NR } \\
2001-2002\end{array}$ & $\begin{array}{c}\text { NR } \\
2003-2012\end{array}$ & $\begin{array}{c}\text { Difference-in- } \\
\text { difference } \\
{[95 \% \mathrm{Cl}]}\end{array}$ \\
\hline \multicolumn{8}{|c|}{ Comparison NRAs and Non NRAs $(\mathrm{N}=25,236)$} \\
\hline \multirow[t]{2}{*}{ Males } & 10,733 & $\begin{array}{c}0.067 * * * \\
(0.020)\end{array}$ & $\begin{array}{c}0.024 * * * \\
(0.010)\end{array}$ & $\begin{array}{l}-0.043^{*} \\
(0.022)\end{array}$ & $\begin{array}{c}0.026 \\
(0.019)\end{array}$ & $\begin{array}{l}-0.007 \\
(0.009)\end{array}$ & $\begin{array}{l}-0.033 \\
(0.020)\end{array}$ \\
\hline & & & & {$[-0.087$ to 0.0004$]$} & & & {$[-0.073$ to 0.007$]$} \\
\hline \multirow[t]{2}{*}{ Females } & 14,503 & $\begin{array}{c}0.079 * * * \\
(0.018)\end{array}$ & $\begin{array}{c}0.035^{* * *} \\
(0.009)\end{array}$ & $\begin{array}{c}-0.045^{* *} \\
(0.020)\end{array}$ & $\begin{array}{l}0.028^{*} \\
(0.017)\end{array}$ & $\begin{array}{c}0.000 \\
(0.009)\end{array}$ & $\begin{array}{l}-0.027 \\
(0.018)\end{array}$ \\
\hline & & & & {$[-0.084$ to -0.006$]$} & & & {$[-0.064$ to 0.008$]$} \\
\hline \multirow[t]{2}{*}{$\begin{array}{l}\text { Less highly } \\
\text { qualified }^{\perp}\end{array}$} & 14,886 & $\begin{array}{c}0.069 * * * \\
(0.017)\end{array}$ & $\begin{array}{l}0.018^{* *} \\
(0.009)\end{array}$ & $\begin{array}{c}-0.051 * * * \\
(0.019)\end{array}$ & $\begin{array}{l}0.039 * * \\
(0.016)\end{array}$ & $\begin{array}{l}-0.003 \\
(0.009)\end{array}$ & $\begin{array}{c}-0.042 * * \\
(0.018)\end{array}$ \\
\hline & & & & {$[-0.088$ to -0.013$]$} & & & {$[-0.077$ to -0.007$]$} \\
\hline \multirow[t]{3}{*}{ Retired } & 5,458 & -0.029 & $-0.094 * * *$ & $-0.064^{*}$ & 0.004 & $-0.056 * * *$ & $-0.060 *$ \\
\hline & & $(0.030)$ & $(0.015)$ & $(0.033)$ & $(0.028)$ & $(0.015)$ & $(0.031)$ \\
\hline & & & & {$[-0.130$ to 0.001$]$} & & & {$[-0.121$ to 0.0006$]$} \\
\hline \multirow[t]{3}{*}{ Receiving Benefits } & 14,563 & $0.072 * * *$ & $0.017^{*}$ & $-0.054 * * *$ & $0.031^{*}$ & -0.005 & $-0.036^{*}$ \\
\hline & & $(0.018)$ & $(0.009)$ & $(0.020)$ & $(0.017)$ & $(0.009)$ & $(0.019)$ \\
\hline & & & & [-0.094 to -0.015$]$ & & & [-0.073 to 0.0006$]$ \\
\hline \multicolumn{8}{|c|}{ Comparison NRAs and Control $1(\mathrm{~N}=6,731)$} \\
\hline \multirow[t]{3}{*}{ Males } & 2,729 & 0.042 & -0.004 & -0.047 & 0.049 & -0.026 & $-0.075^{* *}$ \\
\hline & & $(0.033)$ & $(0.017)$ & $(0.037)$ & $(0.032)$ & $(0.017)$ & $(0.035)$ \\
\hline & & & & {$[-0.119$ to 0.026$]$} & & & {$[-0.144$ to -0.006$]$} \\
\hline \multirow[t]{3}{*}{ Females } & 4,002 & 0.029 & 0.011 & -0.017 & 0.033 & 0.008 & -0.026 \\
\hline & & $(0.031)$ & $(0.015)$ & $(0.035)$ & $(0.029)$ & $(0.015)$ & $(0.032)$ \\
\hline & & & & {$[-0.085$ to 0.050$]$} & & & [0.088 to 0.037$]$ \\
\hline \multirow[t]{3}{*}{ Owner occupiers } & 4,163 & -0.017 & $-0.064 * * *$ & $-0.047^{*}$ & 0.027 & $-0.046 * * *$ & $-0.073 * * *$ \\
\hline & & $(0.025)$ & $(0.013)$ & $(0.028)$ & $(0.024)$ & $(0.013)$ & $(0.026)$ \\
\hline & & & & {$[-0.102$ to 0.008$]$} & & & {$[-0.125$ to -0.021$]$} \\
\hline \multicolumn{8}{|c|}{${ }^{5}$ Model 1 and Model 2 are run for each subgroup separately. } \\
\hline \multicolumn{8}{|c|}{ * Significant at $\mathrm{p} 0.1 ; * *$ at $\mathrm{p} .05 ;{ }^{* * *}$ at $\mathrm{p} 0.01$. Robust standard errors (in parentheses). } \\
\hline \multicolumn{8}{|c|}{ ПVariable by which groups are stratified is dropped as an explanatory variable; all other explanatory variables remain included. } \\
\hline \multicolumn{8}{|c|}{ ¿Less highly qualified are those whose highest educational qualification is GCSE or below. } \\
\hline
\end{tabular}




\section{Figures}

The effect of area based urban regeneration policies on fuel poverty: evidence from a natural experiment in Northern I reland.

Figure 2: Fuel poverty and definition components over the study period by groups: 2001 (wave 1) - 2012 (wave 12)
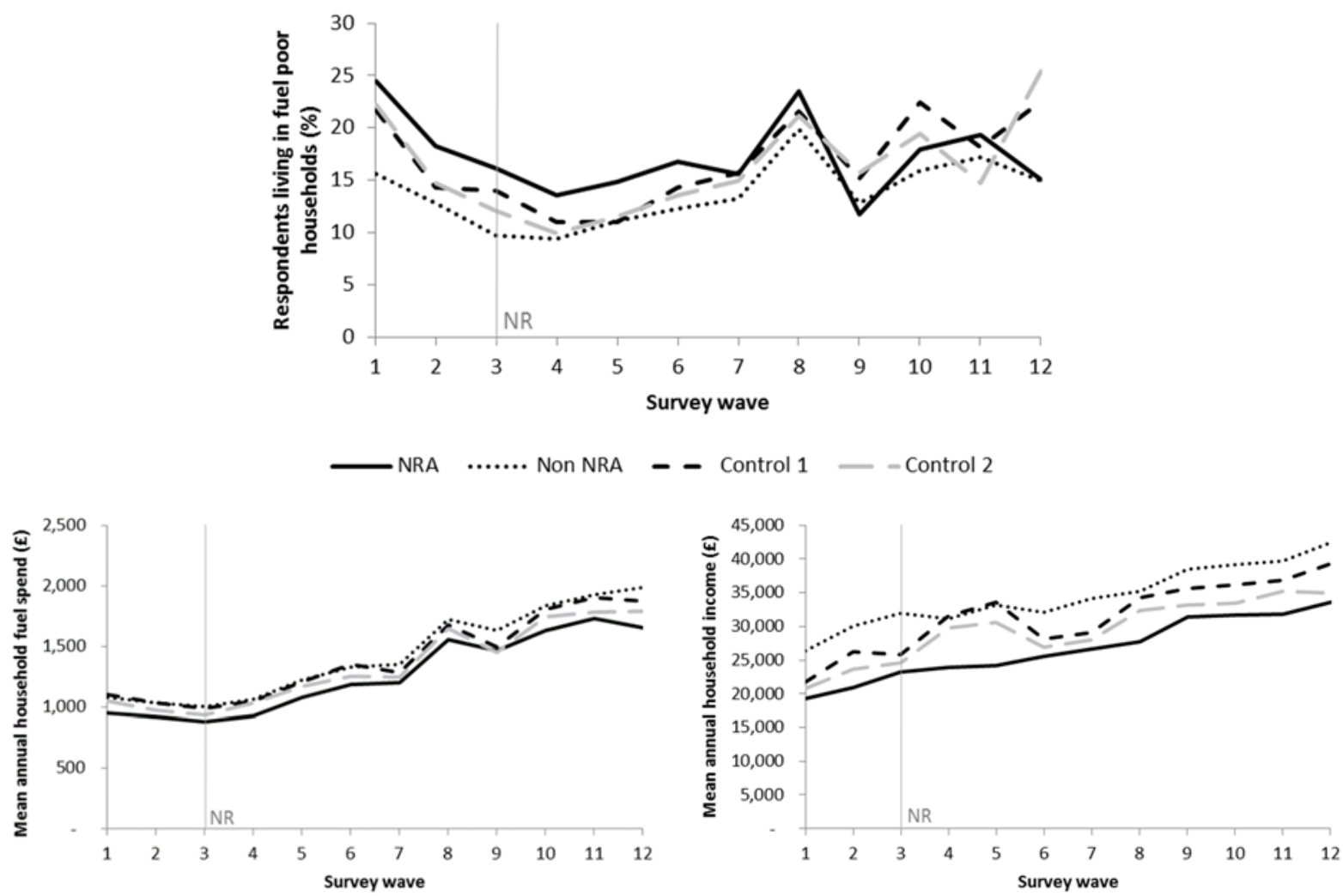
The effect of area based urban regeneration policies on fuel poverty: evidence from a natural experiment in Northern Ireland.

Additional material - Appendix

\section{Contents}

1. Sample characteristics difference tests

2. Responses on damp, central heating, home warmth

3. Parallel trends 'test' result

4. Inverse probability weighting results

\section{Sample characteristics}

Table A-9: Difference tests of characteristics of the sample at wave 1

\begin{tabular}{|c|c|c|c|c|}
\hline & NRA & Non NRA & Control 1 & Control 2 \\
\hline $\mathbf{N}$ & 654 & 2,408 & 222 & 342 \\
\hline \multicolumn{5}{|l|}{ Chi-square tests } \\
\hline & \multicolumn{2}{|l|}{ Degrees freedom } & \multicolumn{2}{|l|}{$\chi^{2}$ value } \\
\hline Female & 1 & 1.2 & 0.6 & 0.1 \\
\hline Education & 5 & $67.8 * * *$ & 4.4 & 2.5 \\
\hline Job status & 6 & $103.5^{* * *}$ & 8.2 & 8.8 \\
\hline Marital status & 3 & $32.3 * * *$ & 3.6 & 1.7 \\
\hline Tenure & 2 & $227.0^{* * *}$ & $14.3^{* * *}$ & $16.0 * * *$ \\
\hline Subjective financial status & 4 & $57.9 * * *$ & 3.2 & 4.4 \\
\hline Benefits & 1 & $28.4^{* * *}$ & $4.2^{*}$ & 0.5 \\
\hline Pension & 1 & $3.6^{*}$ & 0.07 & 0.2 \\
\hline Investment income & 1 & $37.9 * * *$ & 0.06 & 0.1 \\
\hline Dwelling type & 3 & $455.9 * * *$ & $92.4^{* * *}$ & $104.5^{* * *}$ \\
\hline Fuel poor & 1 & $28.2 * * *$ & 0.7 & 0.6 \\
\hline Damp & 1 & $42.8^{* * *}$ & $17.4^{* * *}$ & $35.4^{* * *}$ \\
\hline Central heating & 1 & 0.7 & 0.5 & 0.6 \\
\hline Heating fuel type & 4 & $129.7^{* * *}$ & $12.7^{* *}$ & $20.3^{* * *}$ \\
\hline Would like to move house & 1 & $35.7 * * *$ & $5.6 * *$ & $6.6 * * *$ \\
\hline \multicolumn{5}{|l|}{ t-tests } \\
\hline & & & t-value & \\
\hline Age (mean) & & $1.7^{* *}$ & -0.4 & $1.6^{*}$ \\
\hline Number of children & & $-2.5^{* *}$ & -1.1 & $-1.9 * *$ \\
\hline Mean annual household fuel spend $(f)$ & & $5.6 * * *$ & $3.5^{* * *}$ & $2.7^{* * *}$ \\
\hline Mean annual household income $(£)$ & & $8.6 * * *$ & $2.1^{* *}$ & $1.5^{*}$ \\
\hline
\end{tabular}




\section{Responses over time for damp, central heating, home warmth, prefer to move house}

The number of NRA respondents reporting dampness issues was halved by wave three according to Figure A-3 but this decline halted by wave six with a rise in respondents reporting damp in waves seven and eight. A proliferation of respondents reporting dampness was likewise experienced in the other control groups. Figure A-3 also demonstrates that there was a decline in the proportion of homes that lacked central heating across all groups over the study horizon. A six percent decline in NRA respondents living in homes without central heating occurred between the first and last wave of data ( $13 \%$ and $7 \%$ respectively). In Non NRAs a reduction in households without central heating occurred from wave one (12\%) to wave eight $(4 \%)$, but surprisingly this trend reversed with an increase in respondents living in accommodation without central heating by wave twelve (7\%). Both disadvantaged control groups saw an eleven percent decrease in respondents living in homes without central heating from the first to final wave of data.

Figure A-3: Respondent reporting of living in damp homes and central heating: 2001 (wave 1) - 2008 (wave 8)/ 2012 (wave 12)
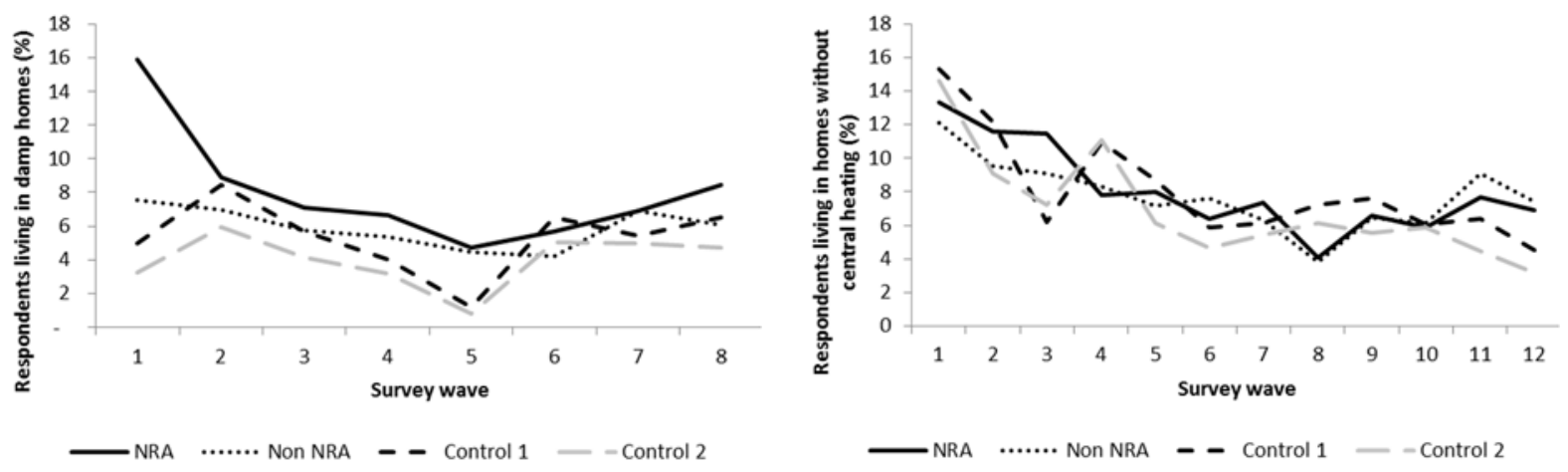

In waves one to eight the BHPS survey asks respondents the question "Do you keep your home adequately warm?" and the yes/no responses for NRAs and Non NRAs are presented in Table A-10. Given the large body of evidence concerning the high prevalence of fuel poverty in NI (Walker et al. 2014; Northern Ireland Housing Executive 2013; Liddell et al. 2012; Department for Social 
Development 2011b; Shortt \& Rugkåsa 2007; Department for Social Development 2004) and the fuel poverty results depicted in Figure 1 of the main paper, the small numbers of "no" responses to this question was surprising. In wave one, only $2.9 \%$ of NRA and $1.3 \%$ of Non NRA respondents said that they did not keep homes sufficiently warm. Following a "no" response to "Do you keep your home adequately warm?" the survey inquires "Would you like to keep your home adequately warm?". Those that respond "yes" might be thought of as fuel poor. It is evident from Table A-10 those in NRAs those who reported not keep their home warm did not do so voluntarily while in Non NRAs some respondents willingly chose not to maintain temperate homes.

Table A-10: Reports among respondents of home warmth

\begin{tabular}{|c|c|c|c|c|c|c|}
\hline \multirow[b]{3}{*}{ Wave } & \multicolumn{4}{|c|}{ Do not keep home adequately warm } & \multicolumn{2}{|c|}{ Would like to keep home adequately warm } \\
\hline & \multicolumn{2}{|c|}{ NRA } & \multicolumn{2}{|c|}{ Non NRA } & \multirow{2}{*}{$\begin{array}{c}\text { NRA } \\
(\%)\end{array}$} & \multirow{2}{*}{$\begin{array}{c}\text { Non NRA } \\
(\%)\end{array}$} \\
\hline & (\%) & $\mathrm{N}$ & (\%) & $\mathrm{N}$ & & \\
\hline 1 & 2.9 & 19 & 1.3 & 32 & 94.7 & 65.6 \\
\hline 2 & 3.1 & 15 & 1.2 & 24 & 86.7 & 62.5 \\
\hline 3 & 1.9 & 9 & 0.8 & 17 & 77.8 & 94.1 \\
\hline 4 & 3.4 & 15 & 1.1 & 20 & 100.0 & 75.0 \\
\hline 5 & 1.4 & 6 & 1.0 & 18 & 100.0 & 77.8 \\
\hline 6 & 3.1 & 13 & 1.1 & 20 & 100.0 & 85.0 \\
\hline 7 & 1.0 & 4 & 1.1 & 19 & 75.0 & 47.4 \\
\hline 8 & 4.9 & 18 & 2.0 & 32 & 100.0 & 75.0 \\
\hline
\end{tabular}

The percentage of respondents reporting they would prefer to move house in Figure A-4 reveals that the greatest reduction in desire to move house was registered in NRAs, while in analogously disadvantaged controls preferences to move fluctuated and the decline for Non NRAs was slight over the period. 


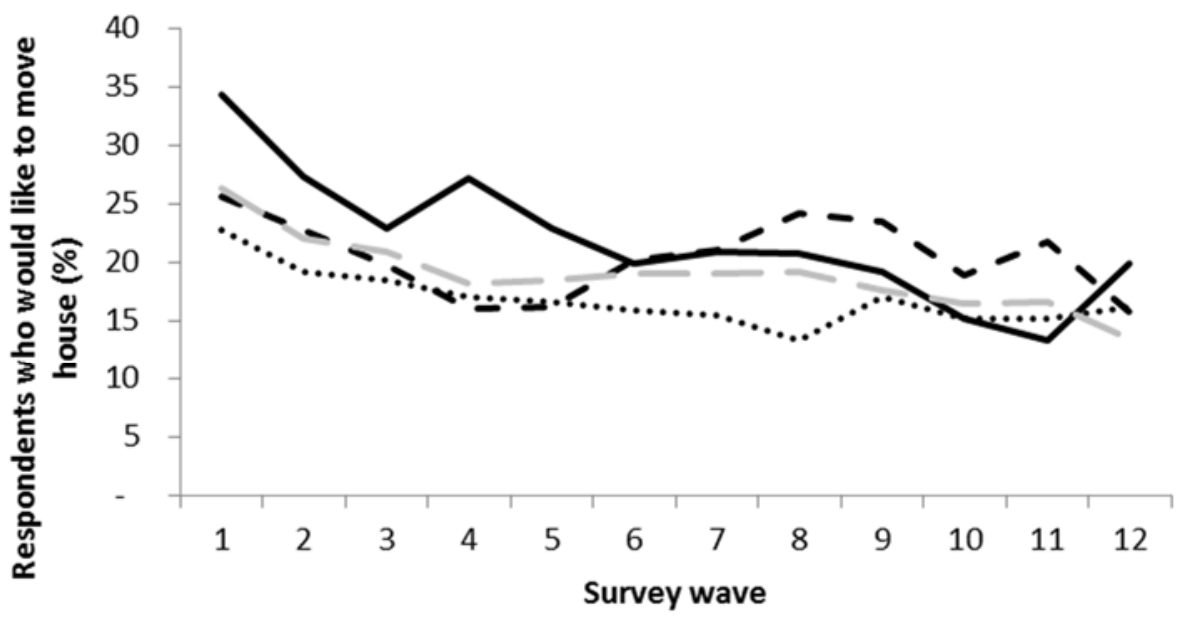

- NRA $\quad$...... Non NRA - - Control $1-$ Control 2

\section{Parallel trends estimation}

Table A-11: Parallel trends test 'estimating' pre-existing trend in fuel poverty between NRAs and controls before NR (wave two)

\begin{tabular}{|c|c|c|c|c|c|c|}
\hline & \multicolumn{2}{|c|}{ NRA v Non NRA $(N=25,236)$} & \multicolumn{2}{|c|}{ NRA v Control $1(\mathrm{~N}=6,731)$} & \multicolumn{2}{|c|}{ NRA v Control $2(\mathrm{~N}=7,632)$} \\
\hline & Model 1 & Model 2 & Model 1 & Model 2 & Model 1 & Model 2 \\
\hline \multicolumn{7}{|l|}{ NR*wave 2} \\
\hline $\begin{array}{l}\text { Coefficient } \\
\text { estimate }\end{array}$ & $\begin{array}{l}-0.034 \\
(0.027)\end{array}$ & $\begin{array}{l}-0.036 \\
(0.025)\end{array}$ & $\begin{array}{c}0.011 \\
(0.045)\end{array}$ & $\begin{array}{l}-0.009 \\
(0.042)\end{array}$ & $\begin{array}{c}0.013 \\
(0.039)\end{array}$ & $\begin{array}{c}0.00005 \\
(0.037)\end{array}$ \\
\hline$p$-value & 0.199 & 0.141 & 0.801 & 0.823 & 0.536 & 0.999 \\
\hline$[95 \% \mathrm{Cl}]$ & {$[-0.086$ to 0.018$]$} & {$[-0.084$ to 0.120$]$} & {$[-0.077$ to 0.099$]$} & {$[-0.092$ to 0.073$]$} & {$[-0.063$ to 0.090$]$} & {$[-0.071$ to 0.072} \\
\hline
\end{tabular}




\section{Inverse probability weighting difference in difference results}

Table A-12: Inverse probability weighting difference in difference results for fuel poverty

\begin{tabular}{|c|c|c|c|c|c|c|}
\hline & \multicolumn{2}{|c|}{ NRA v Non NRA ( $N=25,236)$} & \multicolumn{2}{|c|}{ NRA v Control $1(\mathrm{~N}=6,731)$} & \multicolumn{2}{|c|}{ NRA v Control $2(\mathrm{~N}=7,632)$} \\
\hline & Model 1 & Model 2 & Model 1 & Model 2 & Model 1 & Model 2 \\
\hline \multicolumn{7}{|c|}{ Pre-NR (2001-2002) } \\
\hline Control & 0.143 & 0.094 & 0.181 & 0.096 & 0.187 & 0.100 \\
\hline NRA & 0.219 & 0.122 & 0.219 & 0.140 & 0.219 & 0.138 \\
\hline Pre-NR & $0.076 * * *$ & $0.029 * *$ & 0.038 & $0.044 * *$ & 0.033 & $0.038 * *$ \\
\hline difference & $(0.013)$ & $(0.012)$ & $(0.023)$ & $(0.021)$ & $(0.020)$ & $(0.018)$ \\
\hline \multicolumn{7}{|l|}{ NR (2003-2012) } \\
\hline Control & 0.131 & 0.084 & 0.158 & 0.108 & 0.150 & 0.088 \\
\hline NRA & 0.164 & 0.083 & 0.164 & 0.104 & 0.164 & 0.102 \\
\hline NR difference & $0.03 * * *$ & -0.001 & 0.005 & -0.003 & 0.014 & 0.014 \\
\hline 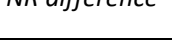 & $(0.007)$ & $(0.006)$ & $(0.011)$ & $(0.011)$ & $(0.010)$ & $(0.009)$ \\
\hline Difference-in- & $-0.044 * * *$ & $-0.029 * *$ & -0.033 & $-0.048 * *$ & -0.018 & -0.023 \\
\hline Difference & $(0.015)$ & $(0.014)$ & $(0.025)$ & $(0.024)$ & $(0.022)$ & $(0.021)$ \\
\hline$[95 \% \mathrm{Cl}]$ & {$[-0.073$ to -0.014$]$} & {$[-0.056$ to -0.002$]$} & {$[-0.082$ to 0.017$]$} & {$[-0.094$ to -0.001$]$} & {$[-0.062$ to 0.025$]$} & {$[-0.063$ to 0.017$]$} \\
\hline $\mathrm{R}^{2}$ & 0.00 & 0.14 & 0.00 & 0.15 & 0.00 & 0.15 \\
\hline
\end{tabular}

i Licence 83566

ii Lower educated group defined as education attainment of mandatory GCSE education (16 years) or less 